\title{
Opinion Children
}

Paul T E Cusack

BScE, DULE, 23 Park Ave. Saint John, NB, E2J 1R2, Canada

Corresponding Author: Paul T E Cusack, BScE, DULE, 23 Park Ave. Saint John, NB, E2J 1R2, Canada.

Received date: July 13, 2020; Accepted date: September 12, 2020; Published date: September 15, 2020

Citation: Paul T E Cusack (2020) Opinion Children. J General Medicine and Clinical Practice. 3(2) DOI: 10.31579/2639-4162/027

Copyright: (2020. Paul T E Cusack This is an open-access article distributed under the terms of the Creative Commons Attribution License, which permits unrestricted use, distribution, and reproduction in any medium, provided the original author and source are credited.

When it comes to children, I wonder if they have an innate ability to do mathematics in the same way it is claimed they do for other language. Math is a language but is more based on graphics. Graphics is a spatial aptitude which boys may be more inclined toward from the time we were hunters and needed spatial aptitude to survive. Girls do as well as boys in math up until puberty. Then the mothering instinct takes over. Women are all about relationships. They lose interest in math because there is little payback to cultivate relationships. Perhaps men outperform women in Science, technology, Engineering and Math because of our genetic inheritance. It may be futile to try to change these inborn skills and interests. Basically, boys and girls are different, and men and women are even more different. Nature has made us that way. Forcing women to be like men is doing damage to the women (and men too). Her instinct is to have children. As women entered the work force, they were expected to have two jobs (or maybe even three). Birth rates are declining in societies where women are pressured to work outside the home. They are characteristically unhappy. We should celebrate women having children in the West. Demographically, it may already be too late.

When it comes to LBGQT rights, there was a US Supreme Court decision on June 15, 2020 that prevents someone being fired from a job because of sexual orientation. Should a country that puts its trust in God institutionalize homosexuality? Adolescents are encouraged to decide if they fall into the LBGQT fold or not. For every young gay person who feels under threat, there is another who is not gay who feels under threat. My heart breaks for the families of those who are living the gay lifestyle. Our Bible tells us, "Males and Female He made them." "It is not good for man to be alone. He should leave his mother and father and take a wife and reproduce and fill the whole world. LBGQT cannot reproduce naturally and they should not. Children be born into this environment is unhealthy. If the adults choose such a contorted lifestyle, so be it. But do not drag the children into it.

When it comes to the family, the nuclear family is the natural way to have support for having and raising happy, holy, and healthy children. Fathers and mothers should not have children if they do not intend to keep their sacred marital vows. Vows are serious. The nuclear family has been destroyed in 3 generations. It may be too late to ever recover from the demise of wholeness where the father and mother support each other and their children. Father's cannot get good jobs to support a family while the mother mother's her own children instead of farming them out at too young an age.

When it comes to having children, abortion kills the unborn as well as the mother. It is the most natural thing for a healthy woman to have a child. To stop that heart from beating is not only morally wrong but should be criminal for patient and doctor alike. It is reported that women are hurt too by killing the unborn, somethings leading to suicide attempts.

So why has the West, once wholesome as late as the 1950's become so antilife? Was it WWII; the Cold War and nuclear threats; drugs and the hippies? Or was it the Protestant Reformation and the loss of absolute Truth? "It is a corrupt generation," the Bible tells us. We see children taking illegal drugs at a young age. Now drug are legal. Schools are not fit schooling in a safe environment, especially with guns on the loose. We see culture wars in the once great USA. Entertainment and sports figures are polluted with drugs, adultery, and fornication and divorce. Moral decadence has run rampant.

There is a lot that can be done to improve children's' health and the parents too. But the solutions are social; not therapeutic. The cost is low, and the success is high, nor research breakthroughs necessary. All it requires is for society to return to God. I was raised in an environment where I was cherished. More than half of the children born today are accidents. I had no children myself because I did not want to put them through what I went through mainly in the school system. That was in the 1970 's. I know it's is worse nowadays. Parents are home schooling their children because schools are unsafe. Has there ever been a time like this in History?

Our current social system is retrogressive. Supreme Court decisions like the one last week institutionalizes the broken family and licentiousness. This is my opinion which is dangerous to express. I wonder how the Supreme Court will make out with the Roe v Wade 1973 decision. Why does the USA say it trusts in God? One of the causes of the fall of the Roman Empire was moral decadence. Sound familiar? All that is necessary for evil to triumph is for good men to do nothing. Edmund Burke 